\title{
COMBINED MICROWAVE-CONVECTIVE DRYING OF SACCHAROMYCES CEREVISIAE BASED YEAST
}

\author{
L. BERECZ ${ }^{\mathrm{a}}, \mathrm{M}$. NEMÉNYI ${ }^{\mathrm{b}}$ and J. R. PUIGGALI ${ }^{\mathrm{c}}$ \\ ${ }^{\text {a }}$ Process Engineering of Agricultural Products, Research Group of the Hungarian Academy of Sciences, \\ Mosonmagyaróvár, H-9200, Vár 2. Hungary \\ ${ }^{\mathrm{b}}$ Pannon Agricultural University, Institute of Agricultural Engineering, Mosonmagyaróvár, \\ H-9200, Vár 2. Hungary \\ ${ }^{\mathrm{c}}$ ENSGTI - Université de Pau et des Pays de l'Adour, Rue Jules Ferry F-6400 Pau. France
}

(Received: 27 July 1998; accepted: 17 February 1999)

Attention is paid to drying as a downstream processing of foodstuff as it is used finally for human consumption. In some cases the conventional (convective, contact or infrared) drying processes can damage the quality of food due to crusting phenomena, overheating or protein denaturation. Better results can be obtained using combined microwave-convective dehydration.

The paper mainly focuses on the investigation of drying Saccharomyces cerevisiae pulp using the method of dielectric dehydration. A dried product with a residual fermentative activity of over $80 \%$ was produced with the application of a microwave-convective drying system. As a result the moisture content was lower than $10 \%$ calculated on dry basis. We permanently regulated the incident microwave power manually in order to eliminate the mentioned disadvantageous effects. This type of regulation was applied when the surface temperature reached $45^{\circ} \mathrm{C}$.

Keywords: microwave-convective drying, Saccharomyces cerevisiae

The rise of temperature of a dielectric material being exposed to an electromagnetic field can be explained by the conversion of electromagnetic energy into heat. This new heating method was discovered about 40 years ago, although the magnetron, which is used to make it, was already used in radar equipment during World War II.

The microwave radiation ranges from $300 \mathrm{MHz}$ frequency up to $300 \mathrm{GHz}$, which corresponds to wavelength $1 \mathrm{~mm}-1 \mathrm{~m}$. From this range $2.45 \mathrm{GHz}$ frequency was selected for the household microwave ovens.

Microwave heating and drying differ from the conventional heating methods essentially. The latter methods are based on the internal friction between weakly bound electrons and molecules. Microwave energy transmission in wet solids can be explained by polarisation of randomly oriented water dipoles. In the $2.45 \mathrm{GHz}$ alternating field the dipoles are forced to change their direction $4.9 \times 10^{9}$ times per second. A part of the 
input energy is converted into heat and results in a very rapid heating. ZAGROUBA and co-workers (1993) found that electromagnetic energy at a frequency of $2.45 \mathrm{GHz}$ can penetrate an object with a thickness of $100 \mathrm{~mm}$ uniformly.

The power dissipated and converted into heat in a unit volume of the material can be expressed by:

$$
\mathrm{P}_{\mathrm{v}}=2 \pi f \mathrm{E}^{2} \varepsilon_{0} \varepsilon^{\prime \prime}
$$

were f: frequency, E: electric field strength, $\varepsilon_{0}$ : permittivity of free space, $\varepsilon^{\prime \prime}$ : dielectric loss factor. The higher the frequency and the electric field strength the higher the amount of energy converted into heat in the material. The dielectric loss factor is a material parameter, which indicates the amount of input microwave loss throughout the volume of the material. The values of dielectric loss factor of water was compiled by ZAGROUBA and co-workers (1993) at frequency $2.45 \mathrm{GHz}$ in function of the temperature (Table 1). It obviously depends on the temperature.

One of the most important applications of the microwave technology is drying. In convective drying the heat gradient is of the opposite direction compared to the mass gradient. Consequently, if the material is dried too rapidly, an impermeable outer crust can form and will not permit moisture diffusion. Moreover, this crust can result in overheating of the surface. Since the direction of the heat gradient is the same as the mass gradient during microwave drying, the mentioned undesirable phenomena can be avoided, therefore the microwave technology is ideal for drying thermosensitive materials. Thermosensitive materials can be favourably dried by combining convective and microwave methods. In this case the moisture migration inside the material can be influenced by the microwave power mainly, and the evaporated water is carried out by the air ventilation at a moderate temperature.

ZAGROUBA and co-workers (1993) investigated the behaviour of a gelatine film and a polyacrylamid sphere during microwave-convective drying. Analysing the obtained drying characteristics, they found the presence of an over pressure drying period owing to the microwave energy, which can seriously damage the product by bursting it.

Table 1

Dielectric loss factor of water at different temperatures

\begin{tabular}{ccccccc}
\hline Temperature $\left({ }^{\circ} \mathrm{C}\right)$ & 0 & 20 & 40 & 60 & 80 & 100 \\
\hline Dielectric loss factor & 20 & 12 & 7 & 4.5 & 2.7 & 2 \\
\hline
\end{tabular}


AYAPPA and co-workers (1991) determined the conditions of the approximate applicability of Lambert's law which was conventionally used to model the microwave heating of finite slabs. The correct power dissipation was computed from Maxwell's equations. They determined the critical slab thickness, above which the Lambert's law is valid. They compiled a wide range of dielectric properties of foods.

BODOR and co-workers (1993) carried out experiments applying microwave treatment to concentrate L-ascorbic acid solutions. They stimulated the crystallisation process using infrared and microwave energy. With special regard to the thermodegradable material, they did not heat it over $50^{\circ} \mathrm{C}$.

TURNER and co-workers (1998) built up a mathematical model for convective and microwave enhanced convective drying of pine wood. Drying periods, rate, moisture profiles and temperature profiles, effective diffusivity were modelled and analysed. They found that the use of combined microwave and convective drying can reduce time and increase drying rate as compared to the convective equivalent. The reduction of drying time depends on the level of incident microwave power.

Combined microwave-convective investigations were carried out on baker's yeast suspension by SZALAY and co-workers (1993). They found that the critical time and critical moisture content were reduced compared to the convective method. They emphasized the importance of the accurate temperature control of the material during the process.

BERECZ and NEMÉNYI (1996) investigated the internal temperature profile of baker's yeast during infrared drying. They determined the critical moisture content of the material, at which crust formation started, by means of temperature profiles and weight changes.

\section{Materials and methods}

Commercial compressed Saccharomyces cerevisiae based yeast was used in the experiments as model material. Its moisture content varied from $200 \%$ to $300 \%$ on dry basis. The purpose of the work was to produce dried yeast with

- maximum 10\% moisture content according to GINZBURG (1979)

- at least $80 \%$ of its original fermentative activity retained (BÉNDEK, 1987).

In the case of yeast drying it is essential to preserve the fermentative activity, which refers to its biological value and characterizes the drying method used. To determine a value for the fermentative activity, the dried yeast was dissolved in a $10 \%$ $(w / w)$ glucose solution and poured into a test tube. After closing the tube with a plug pierced with a capillary tube, the test tube was vertically turned by $180^{\circ}$. Then it was put into a water bath of $20{ }^{\circ} \mathrm{C}$ to assure the necessary temperature for fermentation. Then the fermentation, namely the evolution of carbon dioxide started. The solution was 
forced by carbon dioxide to drop out of the tube and its weight was registered and plotted at intervals by means of a PC. The slope of this line represented the rate of evolution of $\mathrm{CO}_{2}$ (Fig. 1). There were three typical periods: first the "lag" period of microbes, second the exponential growing period and third the falling-rate period of growing when the decrease of substrate molecules began to limit fermentation. The fermentation capacity was characterized by the maximal rate of evolution of $\mathrm{CO}_{2}\left(\mathrm{v}_{1}\right)$. It is obvious that the rate of gas evolution was in direct proportion to the rate of measured weight.

After $t_{1}$ time passed a peak of rate of gas evolution could be observed, then the falling-rate period began. Each fermentation experiment was carried out twice, first using a dehydrated material, then a fresh material without drying with the same dry matter. Maximal rates of gas evolution of dried material $\left(\mathrm{v}_{1 \mathrm{~d}}\right)$ and fresh material $\left(\mathrm{v}_{1 \mathrm{f}}\right)$ were then determined. The residual fermentative activity of dried material was given by

$$
A=v_{1 d} / v_{1 f}
$$

The drying apparatus (ENSGTI, France) was a convective drying tunnel (Fig. 2) equipped with a magnetron $(2.45 \mathrm{GHz})$ with a modulable power between 0 and $800 \mathrm{~W}$.

The convective drying parameters could be varied in the following ranges:

- the air velocity between $0.5 \mathrm{~m} \mathrm{~s}^{-1}$ and $2.5 \mathrm{~m} \mathrm{~s}^{-1}$,

- the temperature between the ambient one and $155^{\circ} \mathrm{C}$,

- the relative air humidity between 12 and $99 \%$.

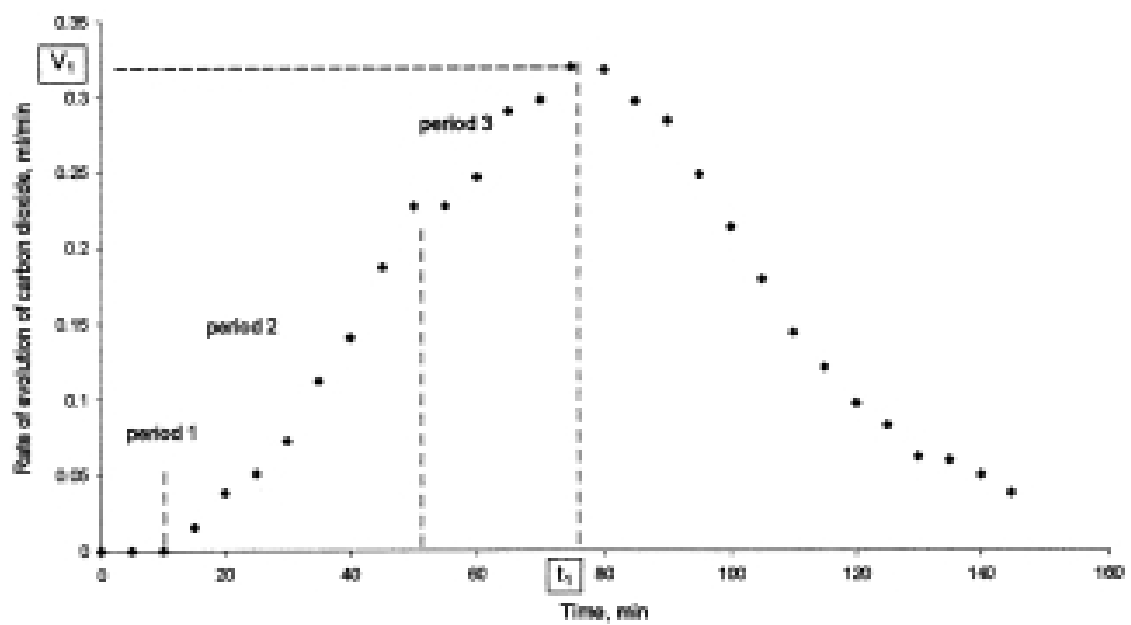

Fig. 1. Evolution rate of carbon dioxide during fermentation 
An example drying rate curve is presented in Fig. 3 in order to get a better insight into the process of drying achieved by means of the mentioned drying tunnel. It describes convective drying. Moisture content is indicated on the abscissa. The process is started at point No. 1 and finished at point No. 4, which is the equilibrium state. The following generalities can be noted: curve of mass flux (right ordinate) can be divided into three principal sections: the constant-rate drying section $(\mathrm{A})$ and the first and second section of falling-rate drying $(B, C)$. The first section of falling-rate drying extends from point No. 2 (as it is the first critical moisture content) to point No. 3 (as it is the second critical moisture content) and the second section of falling-rate drying extends from point No. 3 to point No. 4. The drying rate is controlled by the surrounding drying air during constant-rate period. The surface temperature (left ordinate) of the material is the same as that of the wet bulb temperature of the drying air.

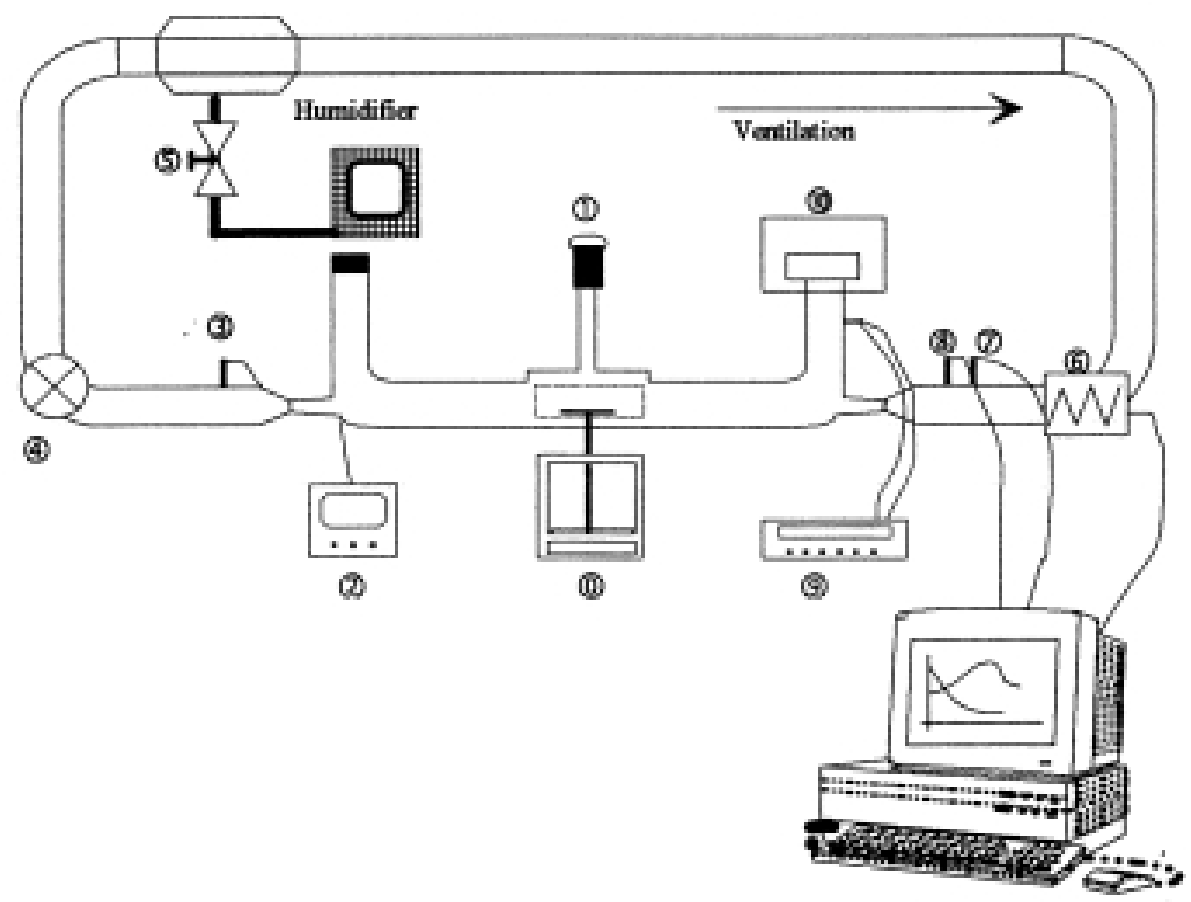

Fig. 2. Experimental drying tunnel. 0: Balance, 1: optic pyrometer, 2: powermeter, 3, 8: thermohygrometer, 4: fan, 5: valve, 6: heater, 7: anemometer, 9: optic thermometer, 10: generator 


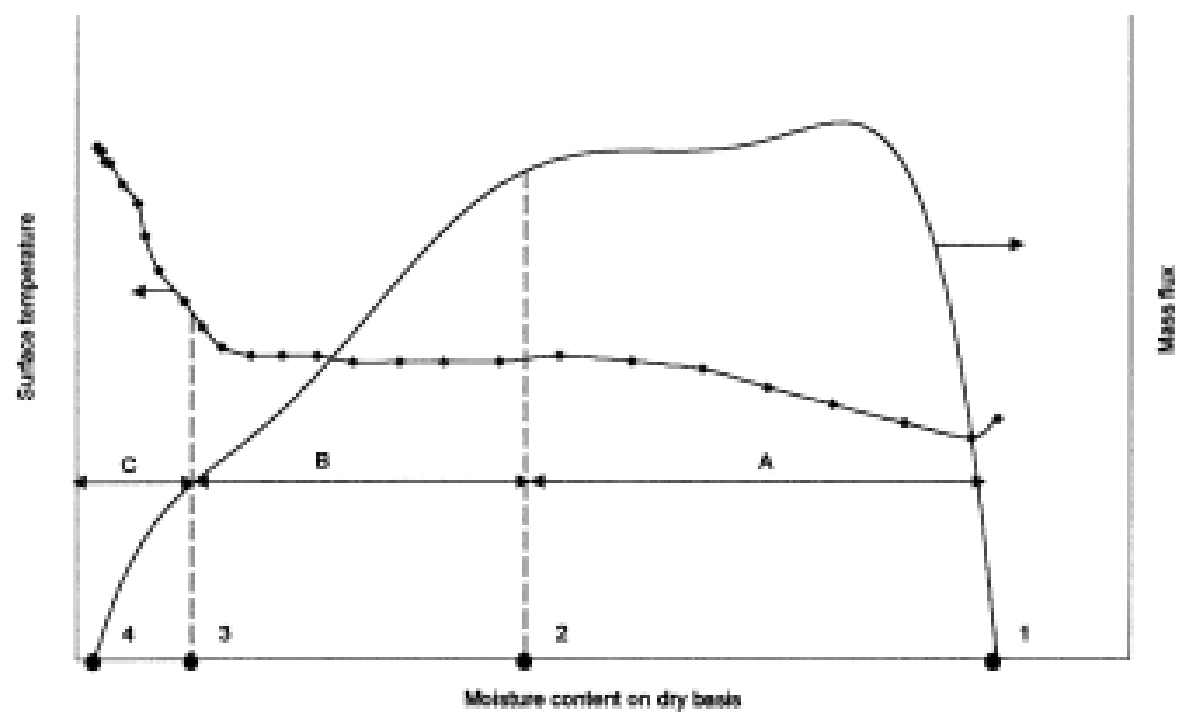

Fig. 3. Drying rate curve with the surface temperature curve. A: constant-rate period, B: first falling-rate period, $\mathrm{C}$ : second falling-rate period

The process is controlled by the resistance of the product to heat and mass flows in the falling-rate stages. Most of the undesirable quality deficiencies (e.g. shrinkage, protein denaturation) can occur during these periods. Surface temperature exceeds the wet-bulb temperature and reaches the dry-bulb temperature.

During the completed drying experiments the layer thickness, air velocity and relative humidity of inlet air remained constant $\left(1 \mathrm{~mm}, 1.2 \mathrm{~m} \mathrm{~s}^{-1} 20 \%\right.$, respectively). The effect of drying temperature on the fermentative activity was investigated at four inlet air temperatures: $39^{\circ} \mathrm{C}, 45^{\circ} \mathrm{C}, 48^{\circ} \mathrm{C}$ and $54^{\circ} \mathrm{C}$.

In combined experiments incident microwave power amounted to $1 \mathrm{~W}$ and $3 \mathrm{~W}$. The samples were disc shaped with $0.1 \mathrm{~cm}$ thickness and $2.5 \mathrm{~cm}$ radius, so the volumetric power was calculated as $0.509 \mathrm{~W} \mathrm{~cm}^{-3}$ and $2.036 \mathrm{~W} \mathrm{~cm}^{-3}$, respectively.

\section{Results}

\subsection{Convective method}

The results of fermentation after convective drying process are represented in Fig. 4. The activity after drying at $45{ }^{\circ} \mathrm{C}$ was close to the required value $(74 \%$ and $80 \%$, respectively). Drying at $48{ }^{\circ} \mathrm{C}$ and $54{ }^{\circ} \mathrm{C}$ resulted in a product, which retained $37 \%$ of 
the original fermentative activity. Degradation, denaturation of enzymatically active proteins started at a temperature of $45-48{ }^{\circ} \mathrm{C}$. The yeast cells preserved their fermentative nature at $39{ }^{\circ} \mathrm{C}$ well. The lower drying temperature provided good circumstances for the viability of microbes, but at atmospheric pressure the drying time could be longer.

\subsection{Combined convective-microwave method}

A possible way to shorten drying time is to combine convective method with microwave power. The drying curves and surface temperature values are shown in Fig. 5. Chapter 2.1. indicates that the ideal inlet air temperature should be $39{ }^{\circ} \mathrm{C}$. Incident microwave power of $0.509 \mathrm{~W} \mathrm{~cm}^{-3}$ and $2.032 \mathrm{~W} \mathrm{~cm}^{-3}$ was added to the convective process. Figure 6 represents the calculated fermentative activity levels which did not reach the required minimum activity value. According to Fig. 5, surface temperatures did not exceed $46.7^{\circ} \mathrm{C}$, therefore this considerable activity loss (more than 30\%) demands an explanation. The possible reason is that oscillated microwave power took effect on the material within the sampled time and resulted in a brief and undetected overheating.

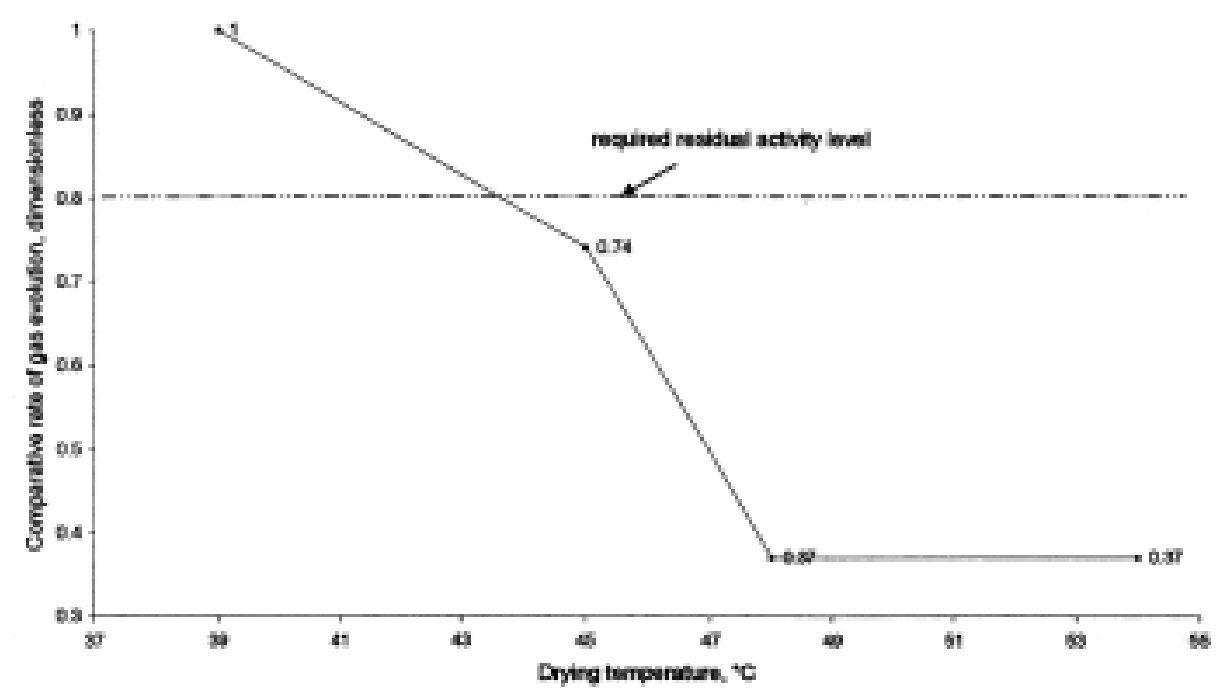

Fig. 4. Fermentation activity of yeast after convective drying at different temperatures 


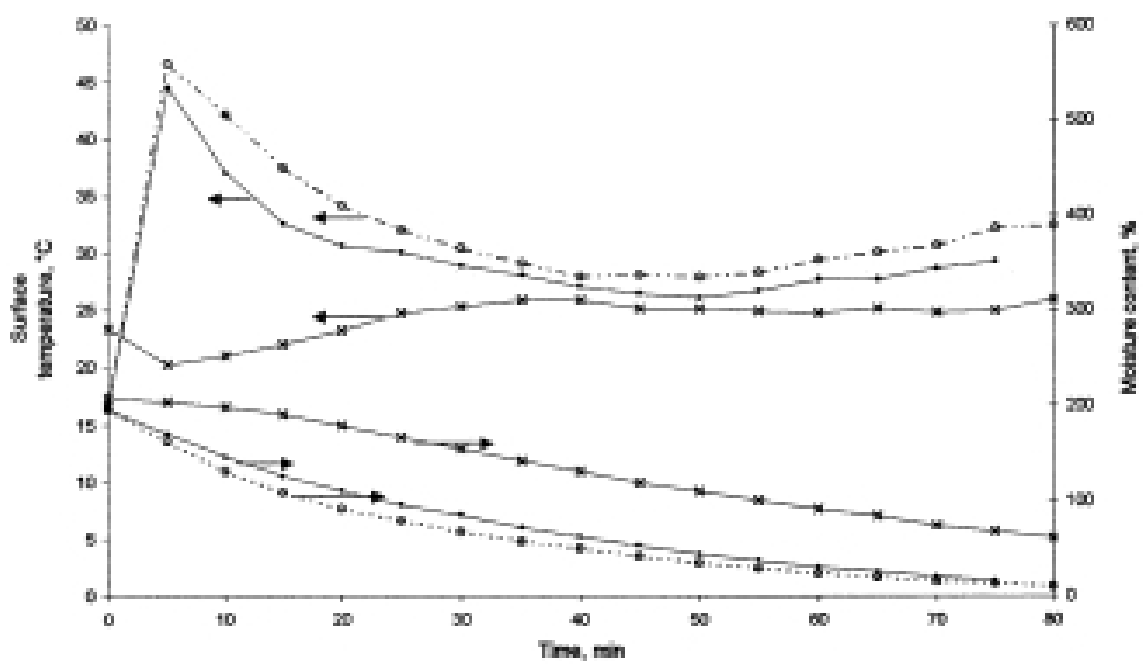

Fig. 5. Convective and microwave enhanced convective drying curves and surface temperatures curves of yeast. X: pure convection at $39^{\circ} \mathrm{C} \bullet$ : convection at $39^{\circ} \mathrm{C}$ with $0.509 \mathrm{~W} \mathrm{~cm}^{-3}$ microwave power $\mathrm{O}$ : convection at $39^{\circ} \mathrm{C}$ with $2.032 \mathrm{~W} \mathrm{~cm}^{-3}$ microwave power

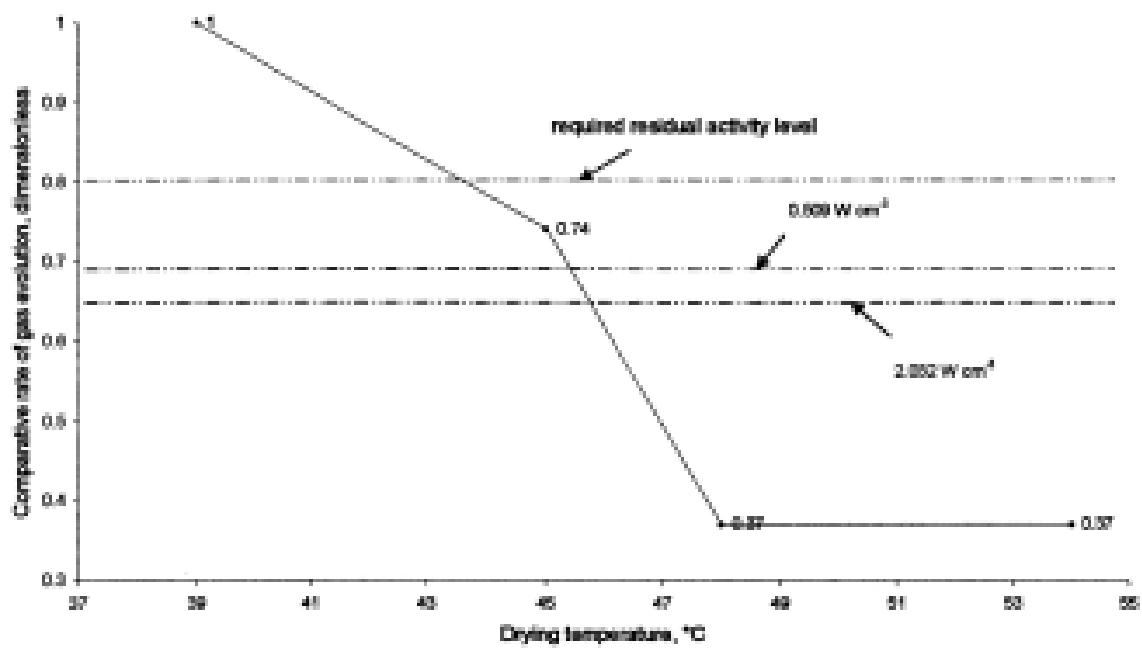

Fig. 6. Fermentation activity of yeast after convective drying at different temperatures (solid line) and combined drying at $39^{\circ} \mathrm{C}$ (dashed line) 


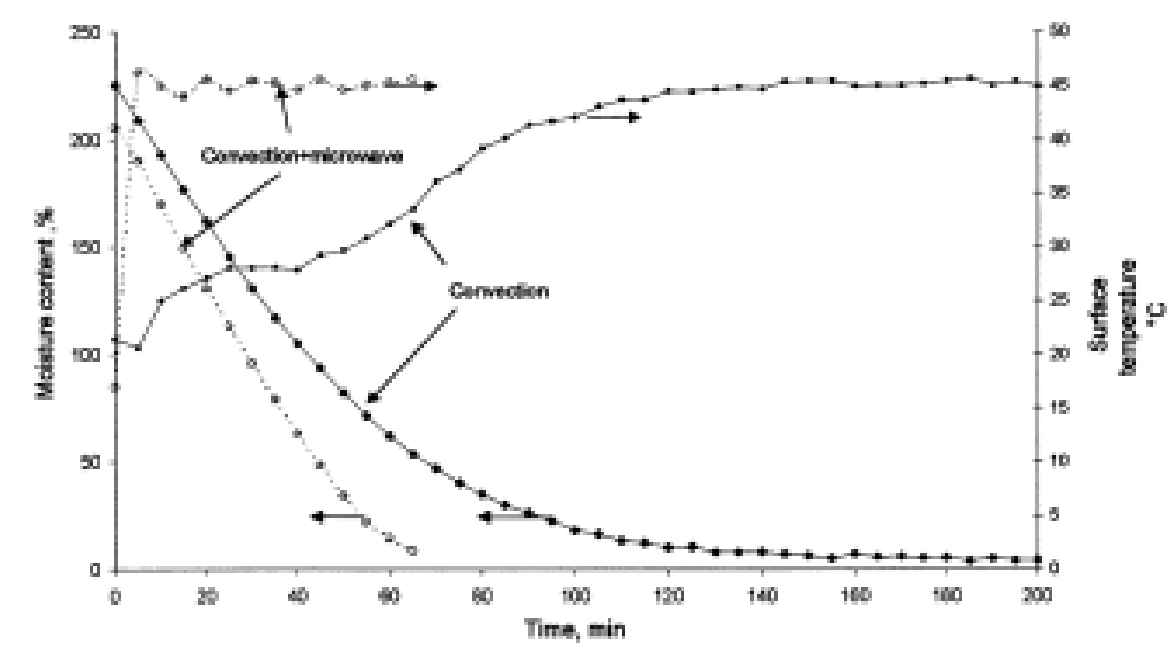

Fig. 7. Convective and enhanced convective drying curves with manual regulation of the incident microwave power

\subsection{Combined convective-microwave method with manual regulation of incident microwave power}

In order to avoid overheating phenomena permanent manual regulation of incident microwave power was performed taking the surface temperature as a basis. The regulation was set into action when the surface temperature attained $45{ }^{\circ} \mathrm{C}$, and the inlet air temperature was $39^{\circ} \mathrm{C}$.

In Fig. 7 a comparison is shown between pure convection (temperature level was $45^{\circ} \mathrm{C}$ ) and the convection method enhanced by microwave. During pure convective process $10 \%$ moisture content was reached after 130 min whereas manual regulation of the indicent microwave power resulted in the same moisture level after $65 \mathrm{~min}$.

The results of the gas evolution experiments for determining the biological value are shown in Table 2. The maximal rate of carbon dioxide formation $\left(0.205 \mathrm{~g} \mathrm{~min}^{-1}\right)$ in the dried material was reached after $130 \mathrm{~min}$. Using fresh material we got values of $0.235 \mathrm{~g} \mathrm{~min}^{-1}$ after $75 \mathrm{~min}$. In order to compare the results, the specific rate of carbon dioxide evolution was introduced, which means the maximal rate of gas evolution divided by the dry matter. In this way the rate of gas evolution can be calculated per unit of dry matter. The final fermentative activity referring to the biological activity of the material can be obtained by dividing the specific gas evolution rate of the dried material 
by the specific gas evolution rate of the fresh material. For getting a percentage, the results are to be multipled by 100 :

$$
0.447 / 0.550 \times 100=81.27 \%
$$

Table 2

Results of yeast fermentation after manually regulated convective-microwave drying

\begin{tabular}{ccc}
\hline & Dried material & Fresh material \\
\hline $\mathrm{t}_{1}(\mathrm{~min})$ & 130 & 75 \\
$\mathrm{v}_{1}\left(\mathrm{~g} \mathrm{~min}^{-1}\right)$ & 0.205 & 0.235 \\
Dry matter $(\mathrm{g})$ & 0.429 & 0.427 \\
\hline $\begin{array}{c}\text { Specific rate evolution of } \\
\text { carbon dioxide }\left(\mathrm{min}^{-1}\right)\end{array}$ & 0.447 & 0.550 \\
\hline
\end{tabular}

This value met $80 \%$ of the residual activity level, as required.

\section{Conclusions}

Our study indicated the effect of microwave enhanced convective drying on the activity of Saccharomyces cerevisiae based yeast. The drying time shortened and the drying intensity increased.

The temperature profiles of the material are of primary importance because of the presence of thermosensitive enzymes. The use of constant incident microwave power could be the cause of either overheating of the material or inefficient dehydration during the process. Consequently, the incident microwave power had to be regulated on the basis of the material temperature. A dried product with a moisture content of $8 \%$ was produced, which retained $81 \%$ of its original fermentative activity.

Further investigations are needed to be able to determine the yeast's dielectric properties being essential to calculate some process parameters.

The authors would like to thank the French Government and the Hungarian Ministry of Education (project: FKFP 1005/1997) for the research support. 


\section{References}

AYAPPA, K. G., DAVIS H. T., CRAPISTE, G. \& GORDON, J. (1991): Microwave heating: an evolution of power formulations. Chem. Engng. Sci., 46, 1005-1016.

BÉNDEK, GY. (1987): Söripari minőségellenőrzés. (Brewing quality control) MÉTE Söripari Szakosztály, Budapest pp. 182-184.

BERECZ, L. \& NEMÉNYI, M. (1996): Az élesztőszáritás hőfizikai alapjai. (Thermophysical bases of yeast drying.) Proceedings of the 26th Ovár's Scientific Days, New Challenges and Strategies in the Agricultural Production. Pannon Agricultural University, Mosonmagyaróvár, pp. 913-919.

Bodor, B., SZAlay, A., SZENTMARJAY, T., ZAGroubA, F. \& RoQueS, M. A. (1993): Formation des cristaux de vitamine $C$ sous un champs hyperfréquence. Recueil des resumés entendus, Comité pour le Développement du Génie des Procédés Chambéry-Grenoble-St.Etienne, Grenoble, pp. 131-132.

GINZBURG, A. SZ. (1979): Az élelmiszerek szárítástechnológiája. (Drying technology of foods.) Mezőgazdasági Kiadó, Budapest, pp. 73-93.

SZALAY, A. BODOR, B. \& SZENTMARJAY, T. (1993): Effect of microwave energy on drying and crystallization. Proceedings of the 8th International Conference on Thermal Engineering and Thermogravimetry. House of Technology, Budapest, p. 287.

TURNER, I., PUIGGALI, J. R. \& JOMAA, W. (1998): A numerical investigation of combined microwave and convective drying of a hygroscopic porous material: a study based on pine wood. Trans ICHemE, Vol. 76, Part A, February, pp. 193-209.

ZaGrouba, F., RoQues, M. A., SZENTMARJay, T. \& SZALAY, A. (1993): Effects of high frequency electromagnetic field on heat sensitive media, I-II. Hung. J. ind. Chem., 21, 65-74; 149-158. 